\title{
THE ASSOCIATION BETWEEN MEDITERRANEAN DIET AND EMOTIONAL STATUS AMONG UNIVERSITY STUDENTS
}

\author{
Üniversite Öğrencilerinde Akdeniz Diyeti ile Duygu Durum İlişkisi
}

\author{
Duygu METiN ${ }^{10}$, Binnur OKAN BAKIR ${ }^{2}$
}

\begin{abstract}
This study is carried on 277 university students registered to faculty of health sciences in a private univerity in order to assess compliance with the Mediterranean diet and its relationship with mood. Participants' sociodemographic characteristics; income level; school performance; participation in social activities; willingly choosing the registered department were also asked as well as their anthropometric measurements. Mediterranean diet adaptation scale was used to determine Mediterranean diet adherence scores. Beck Depression Scale and Profile of Mood States were used to determine the mood states of the individuals. As a result of our study, the majority of the participants were found compatible with the Mediterranean diet (75.8\%) and at normal depression status (59.6\%). A significant relationship was found between adherence to the Mediterranean diet and emotional states of tense, angry, energetic, fatigued $(p<0.05)$. No significant relationship was found between the Mediterranean diet scores and the Beck depression scores ( $p>0.05)$. The relationship between Mediterranean diet and depression should be examined in more details and individuals' awareness for the relationship between mood and nutrition should be increased.

Keywords: Mediterranean diet, mood states, Beck depression inventory.
\end{abstract}

\section{Özet}

Bu çalışma üniversite öğrencilerinde Akdeniz diyetine uyum ile duygu durum ilişkisini değerlendirmek amacıyla bir vakıf üniversitesinde sağlık bilimleri fakültesinde okuyan 277 öğrenci ile yapılmıştır. Katılımcıların sosyodemografik özellikleri, gelir düzeyi, okul başarısı, sosyal faaliyetlere katılım ve bölümü isteyerek seçme durumu sorgulanmış, aynı zamanda antropometrik ölçümleri kaydedilmiştir. Çalışmamızda Akdeniz diyeti uyum skorlarını belirlemek amacıyla Akdeniz diyeti uyum ölçeği kullanılmıştır. Bireylerin duygu durumlarını saptamak amacıyla Beck depresyon ölçeği ve Duygu durum profili ölçeği kullanılmıştır. Çalışmamızın sonucunda katılımcıların çoğunluğunun Akdeniz diyetine uyumlu $(\% 75,8)$ ve depresyon durumunun normal $(\% 59,6)$ olarak bulunmuştur. Akdeniz diyetine uyum ile gerginlik, öfkeli olma, enerjik olma ve yorgunluk arasında anlamlı ilişki bulunmuştur $(p<0,05)$. Akdeniz diyet skoru ile Beck depresyon skoru arasında anlamlı ilişki bulunamamıştır ( $p>0,05)$. Sonuç olarak Akdeniz diyeti ile depresyon ilişkisinin daha detaylı incelenmesi ve bireylerin duygu durumu ile beslenme ilişkisinde farkındalıklarının artırılması önerilmektedir.

Anahtar kelimeler: Akdeniz diyeti, duygu durum, Beck depresyon ölçeği.

1- Yeditepe Üniversitesi Sağlık Bilimleri Enstitüsü Beslenme ve Diyetetik Bölümü, İstanbul, Türkiye 2- Yeditepe Üniversitesi Sağlık Bilimleri Fakültesi Beslenme ve Diyetetik Bölümü, İstanbul, Türkiye

Sorumlu Yazar / Corresponding Author: Öğr. Üyesi Dr. Binnur OKAN BAKIR e-posta / e-mail: binnur.bakir@yeditepe.edu.tr Geliş Tarihi / Received: 04.02.2021, Kabul Tarihi / Accepted: 22.03.2021

ORCID: Duygu METIN: 0000-0003-0806-6058

Binnur OKAN BAKIR: 0000-0002-0448-4300

Nasıl Atıf Yaparım / How to Cite: Metin D, Okan Bakır B. The association between mediterranean diet and emotional status among university students. ESTUDAM Public Health Journal. 2021;6(2):159-68. 


\section{Introduction}

The Mediterranean style nutrition model includes high amounts of olive oil, olives, fruits, vegetables, cereals (mostly whole grains), legumes and seeds; moderately or high levels of fish, moderately eggs, poultry and dairy products and low levels of red meat and products (1). Diet may affect inflammation: a Mediterranean diet model rich in vegetables, fruits and olive oil, is related with lower levels of inflammatory markers, probably due to the anti-inflammatory features of antioxidants (2). In the Mediterranean diet, plant foods are consumed in higher quantities and synergistically improve health with monounsaturated, polyunsaturated, omega-3 fatty acids, antioxidants, fiber and micronutrients (3). International guidelines consider the Mediterranean diet among the advised healthy dietary models, and the United Nations Educational, Scientific and Cultural Organization (UNESCO) regarded the Mediterranean diet an "Intangible Cultural Heritage of Urgent Safeguarding" (4).

QOn the other hand, depression is a worldwide disease affecting more than 300 million people globally. It has been described as sadness, reluctance, pessimism, worthlessness, inadequacy, weakness, decreased activity, stagnation, slowdown in physiological functions however it is different from daily usual mood fluctuations. It can become a serious health problem especially in long time. The least of all, individual performs poorly at work, school resulting in decreased productivity and at worst, depression may even lead to suicide. According to the $2018 \mathrm{WHO}$ report, 800,000 individuals commit suicide every year while the second important cause of death between the ages of 15 and 29 is suicide (5).
By 2020 , depression was expected to have a second burden of disease after heart diseases. The World Health Organization described depression as a global crisis that $19.5 \%$ of the mental illnesses are depression-based in Europe (6). In Turkey, psychiatric disorders of depressive type was also the highest among the psychiatric disorders that requiring aid of psychiatric treatment (7). In a study conducted among university students, it is also stated that depression is the most important mental disorder among university students (8).

Additionally to overall health benefits of the Mediterranean diet, it is suggested to be effective on mental health while it is accepted that nutrients and nutrition affect mood and behavior and contribute to both physical and emotional well-being. Emotional status also affects individual's choices and decisions about what kind of foods to consume. It is known that deficiency of various nutrients not only lead to depressed mood and cognitive disfunction but also known to be contributive to aggressive behavior. The importance of signals in the brain-gut axis in the emergence of nutrition on mood, behavior and cognition are better understood recently (9). The Mediterranean diet was found inversely related to the risk of depression (10). The Mediterranean diet focuses on vitamin B and omega 3 fatty acids as well moderating or limiting the intakes of inflammatory foods, explaining the possible mechanisms associated with depression (11). The aim of this study is to investigate the relationship between the Mediterranean diet and emotional status among university students, thus to enable appropriate interventions for the prevention of depression. 


\section{Study Design and Participants}

After the approval of the Ethics Committee with date 10/10/2019 and number 1736, students who are studying in Faculty of Health Sciences $(n=720)$ and fit in with inclusion criteria at a private university in Istanbul were included between October 2019 and January 2019, and interviewed face to face. For 720 universe sizes, the sample number is calculated as 254 with $5 \%$ acceptable error, 95\% confidence level as it has been shown that depression prevelance was $38.3 \%$ among university students (8) and we completed the study with 277 participants. Participants were included with simple randomisation who were between 18-65 years old with the criteria as being volunteer, without any disease that require a specific dietary restriction, not pregnant/lactating. In order to eliminate confounder factors; the individuals diagnosed with a psychiatric disease previously and/or currently, and smokers and individuals who have an alcholol consumption $>1$ glass of wine/day were not included in the study as alcohol and smoking affect mood. The other factors including sex, body weight, income level, maritial status, participation in social activities, willingly preference of the registered department, which also may affect mood, were also questioned. Additionally, it was ensured that the data collection periods were not in the exam weeks (midterm/final exams etc.). To prevent from bias resulting from the expected high scores of the students from the department of nutrition and dietetics, the difference between adherences to the Mediterranean Diet among all departments was analysed previously to further analyses.

The data is collected by the Mediterranean Diet Adherence Scale and Beck Depression Scale, Emotional Status Profile Scale. A data collection form was used for participants' sociodemographic characteristics including age, gender, marital status, and class, and income level, school performance with Cumulative Grade Point Average (CGPA), participation in social activities, the state of willingly choosing their department as well as their anthropometric measurements (body weight and height).

\section{Mediterranean Diet Adherence Scale}

Martinez-Gonzalez et al. developed mediterranean diet adherence scale in 2012 (11). Pehlivanoğlu, Balcıoğlu, and Ünlüoğlu performed the Turkish validity and reliability. A total score of 7 or above indicates that the individual has an acceptable degree of adherence with the Mediterranean diet, whereas a score of 9 or above indicates that the individual has a strict adherence with the Mediterranean diet (12).

\section{Beck Depression Scale}

Beck et al. developed beck depression scale in n 1961 (13). The Turkish validity and reliability of the scale was performed by Teğin and Hisli $(14,15)$. The number next to each question (ranging from 0 to 3 ) indicates the score to be assigned to that question. Depression score is obtained with the sum of those points. The highest score that can be obtained from the scale is 63 (21 itemsx3 points). The higher total score indicates the high level or severity of depression.

\section{Emotional Status Profile}

Emotional status profile scale was developed by McNair, Lorr, Droppleman (16). Validity and reliability was performed by Selvi et al. (17). The questionnaire contains 65 words/statements that describe the feelings people have. The test requires indicating for each word or statement how it has been feeling in the past week, including the current day.

\section{Sociodemographic Characteristics and Anthropometric measurements}

Sociodemographic characteristics including age, gender, and marital status were collected by a data collection form; anthropometric measurements such as body weight and height was measured. Body weight was measured by the Seca brand portable weighing scale and height by the Seca brand portable height meter. Height length feet side by side; head, hip, foot heels to touch the wall and the Frankfurt plane (eye and ear bucket in line with the top) is measured. Body mass index (BMI) was calculated with weight/(height) 2 formula. 
According to the World Health Organization (WHO) BMI classification was as: BMI <18.5 $\mathrm{kg} / \mathrm{m}^{2}$ as underweight; $18.5-24.9 \mathrm{~kg} / \mathrm{m}^{2}$ as normal body weight; $25-29.9 \mathrm{~kg} / \mathrm{m}^{2}$ as overweight; $\geq 30 \mathrm{~kg} / \mathrm{m}^{2}$ as obese (18).

\section{Statistical Analyses}

SPSS 18.0 statistical package program used in Windows. The suitability of the variables to normal distribution examined using the Kolmogorov-Smirnov test. Descriptive analyzes calculated using mean \pm standard deviation for normally distributed

\section{Results}

\section{General Characteristics}

The mean age of the participants was $21.07 \pm 1.8 ; 37.9 \%$ of the students were in department of nutrition and dietetics; $33.2 \%$ were in nursing; and $28.9 \%$ were in physiotherapy. $30 \%$ of participants were at 1 st class; $27.4 \%$ were at 2 nd class; $26 \%$ were at 3 rd class; $16.6 \%$ were at 4 th class. The mean BMl of the participants was $21.51 \pm 3.26 \mathrm{~kg} / \mathrm{m}^{2}$ and $12.8 \%$ of the students were underweight; $76.9 \%$ of students were at normal body weight; $8.4 \%$ of students were overweight; $1.8 \%$ of students were obese. Only $0.7 \%$ of the participants were married and $92.4 \%$ of the students were women variables. Nominal variables given using frequency and percentages. The correlation between normally distributed parameters was investigated with Pearson's rho correlation coefficient. Student t-test is used in the evaluation of differences between two groups, One-Way Analysis of Variance (ANOVA) is performed for comparison of three or more groups and Pearson Chi-Square test for analysis of categorical variables. A $p$ value $<0.05$ was accepted as statistical significance.

Table 1: The relationship of the department attended by the participants with adherence with the Mediterranean diet.

\begin{tabular}{lccccccc}
\hline \multirow{2}{*}{$\begin{array}{l}\text { Mediterranean diet } \\
\text { adherence status }\end{array}$} & \multicolumn{2}{c}{$\begin{array}{c}\text { Nutrition and } \\
\text { Dietetic }\end{array}$} & \multicolumn{2}{c}{ Nursing } & \multicolumn{2}{c}{ Physiotherapy } & \multirow{2}{*}{$\mathbf{p}$} \\
\cline { 2 - 7 } & $\mathbf{n}$ & $\%$ & $\mathbf{n}$ & $\%$ & $\mathbf{n}$ & $\%$ & \\
\hline Compatible & 85 & 81.0 & 65 & 71.4 & 59 & 73.8 & \multirow{2}{*}{0.28} \\
Incompatible & 20 & 19.0 & 26 & 28.6 & 21 & 26.2 & \\
\hline
\end{tabular}

${ }^{*} p<0.05$. Pearson Chi-Square test was used for evaluation.

Regarding Beck depression scores (BDS), $59.6 \%$ of the participants were normal, $32.1 \%$ had mild, and $8.3 \%$ had moderate and severe depression. The mean value for Beck depression score (BDS) was $9.23 \pm 6.6$. Table 2 shows the factors affecting depression status. There was no significant while $7.6 \%$ were men.

Mediterranean diet (MD) adherance was $75.8 \%$ among the total participants. The mean MD score was $7.65 \pm 1.8$. The minimum MD score value was 2 and the maximum was 13. Table 1 shows the relationship between the adherences of the participants to the MD according to their departments. Most of the students at the nutrition and dietetics $(81 \%)$, nursing $(71.4 \%)$ and physiotherapy $(73.8 \%)$ departments were found to be compatible with the Mediterranean diet. There was no significant difference between the departments in compliance with the Mediterranean diet $(p=0.28)$. 
Table 2: The relationship between relevant factors and beck depression scale.

\begin{tabular}{lcccc}
\hline Parameters & $\mathbf{n}$ & Mean & SD $^{*}$ & Significance $^{* *}$ \\
\hline Level of income & & & & \\
$\quad$ Low income & 40 & 11.40 & 7.175 & $\mathrm{~F}=2.638$ \\
$\quad$ Middle income & 171 & 9.05 & 6.751 & $\mathrm{p}=0.073$ \\
$\quad$ High income & 61 & 8.43 & 5.943 & \\
\hline School success & 136 & 8.48 & 6.148 & $\mathrm{~F}=1.691$ \\
$\quad$ CPGA >3.00 & 124 & 9.94 & 7.190 & $\mathrm{p}=0.186$ \\
$\quad$ CPGA 2.00-3.00 & 15 & 10.07 & 6.808 & \\
$\quad$ CPGA <2.00 & & & & \\
\hline $\begin{array}{l}\text { Participation in social } \\
\text { activities }\end{array}$ & & & & $\mathrm{F}=1.721$ \\
$\quad$ Frequently & 59 & 7.90 & 6.285 & $\mathrm{p}=0.181$ \\
$\quad$ Occasionally & 170 & 9.44 & 6.752 & \\
$\quad$ Rarely & 48 & 10.15 & 6.748 & $\mathrm{t}=-1.099$ \\
\hline $\begin{array}{l}\text { State of willingly } \\
\text { preferring the department }\end{array}$ & & & $\mathrm{p}=0.273$ \\
$\quad$ Yes & 243 & 9.07 & 6.514 & \\
$\quad$ No & 34 & 10.41 & 7.719 & $\mathrm{~F}=0.876$ \\
\hline BMI & & & $\mathrm{p}=0.418$ \\
$\quad$ Underweight & 35 & 8.23 & 5.976 & \\
$\quad$ Normal weight & 210 & 9.13 & 6.518 & \\
$\quad$ Overweight and Obese & 28 & 10.43 & 7.579 & \\
\hline Mediterranean diet & & & 6.207 & \\
adherence status & 67 & 9.33 & 6.828 & \\
$\quad$ Compatible & 9.2 & & \\
$\quad$ Incompatible & 210 & & & \\
\hline
\end{tabular}

*Standard deviation, **t=Independent Samples Test, F=One way ANOVA

A significant correlation was found between adherence to the MD and emotional states of tense $(p<0.001)$, angry $(p<0.001)$, energetic $(p=0.04)$ and fatigued $(p<0.001)$. The feeling of tension, anger, energetic and fatigued were higher in MD compatible group (Table 3).

A significant relationship was found between low-income status ( $p=0.04)$; state of willingly preferring the department $(p=0.03)$; BMI $(p=0.04)$ and being angry. Individuals with low income had a higher sense of being angry. Participants who willingly choosed the department was found to be less angry. Individuals with high BMl was found to be angrier. A significant relationship was found between state of willingly preferring the department $(p=0.02)$ and mood of unhappy. Individuals who did not choose the department willingly were found to be more unhappy. 
Table 3: Mediterranean diet and profile of mood states.

\begin{tabular}{|c|c|c|c|c|c|}
\hline \multirow{3}{*}{$\begin{array}{l}\text { Profile of } \\
\text { mood states }\end{array}$} & \multicolumn{5}{|c|}{ Mediterranean diet adherence status } \\
\hline & \multicolumn{2}{|c|}{ Compatible } & \multicolumn{2}{|c|}{ Incompatible } & \multirow[b]{2}{*}{$\mathbf{p}$} \\
\hline & $\mathbf{n}$ & $\%$ & $\mathbf{n}$ & $\%$ & \\
\hline \multicolumn{6}{|l|}{ Tense } \\
\hline $\begin{array}{l}\text { Not at all and } A \\
\text { little }\end{array}$ & 79 & 74.5 & 27 & 25.5 & \multirow{3}{*}{$<0.001^{*}$} \\
\hline Moderately & 67 & 77 & 20 & 23 & \\
\hline $\begin{array}{l}\text { Quite a lot and } \\
\text { Extremely }\end{array}$ & 62 & 77.5 & 18 & 22.5 & \\
\hline \multicolumn{6}{|l|}{ Angry } \\
\hline $\begin{array}{l}\text { Not at all and A } \\
\text { little }\end{array}$ & 79 & 74.5 & 27 & 25.5 & \multirow{3}{*}{$<0.001^{*}$} \\
\hline Moderately & 41 & 74.5 & 14 & 25.5 & \\
\hline $\begin{array}{l}\text { Quite a lot and } \\
\text { Extremely }\end{array}$ & 37 & 82.2 & 8 & 17.8 & \\
\hline \multicolumn{6}{|l|}{ Unhappy } \\
\hline $\begin{array}{l}\text { Not at all and } A \\
\text { little }\end{array}$ & 131 & 74.9 & 44 & 25.1 & \multirow{3}{*}{0.78} \\
\hline Moderately & 39 & 79.6 & 10 & 20.4 & \\
\hline $\begin{array}{l}\text { Quite a lot and } \\
\text { Extremely }\end{array}$ & 30 & 75 & 10 & 25 & \\
\hline \multicolumn{6}{|l|}{ Energetic } \\
\hline $\begin{array}{l}\text { Not at all and A } \\
\text { little }\end{array}$ & 55 & 76.4 & 17 & 23.6 & \multirow{3}{*}{$0.04^{*}$} \\
\hline Moderately & 61 & 71.8 & 24 & 28.2 & \\
\hline $\begin{array}{l}\text { Quite a lot and } \\
\text { Extremely }\end{array}$ & 83 & 79 & 22 & 21 & \\
\hline \multicolumn{6}{|l|}{ Fatigued } \\
\hline $\begin{array}{l}\text { Not at all and A } \\
\text { little }\end{array}$ & 59 & 73.8 & 21 & 26.3 & \multirow{3}{*}{$<0.001^{*}$} \\
\hline Moderately & 45 & 72.6 & 17 & 27.4 & \\
\hline $\begin{array}{l}\text { Quite a lot and } \\
\text { Extremely }\end{array}$ & 96 & 78.7 & 26 & 21.3 & \\
\hline
\end{tabular}

*Pearson Chi-Square test was used for evaluation.

The mean score of adherence with the MD of the participants with normal depression level was 7.23 \pm 1.8 . The minimum MD score value was 2 and the maximum value was 11 . The MD score mean of individuals with mild depression was $7.64 \pm 1.7$. Minimum value was 3 , maximum value was 13 . The mean MD score of individuals with moderate and severe depression was $7.70 \pm 1.6$. Minimum value was 4 , maximum value was 10 . Correlation analysis showed that there was no significant relationship between MD scores and depression status $(p=0.638) \quad($ Table 4).

Table 4: Correlation between MD scores and Beck depression scores (BDS).

\section{Correlation between}

Meditterian Diet scores and

Beck Depression Scores

*Pearson's rho correlation coefficient 
Well-being is important for positive mental health in university students and affects their careers. Many factors affect students' mental health including a healthy lifestyle (19). Today, it is well known that individuals' dietary patterns and mental health are closely related. In the Follow-up SUN Project study, the relationship between MD compliance and depression incidence was investigated with MD compliance scale among 10094 healthy Spanish university students. After 4 years of follow-up, 480 new cases of depression were identified. A lower risk of depression was found in individuals with high compliance with the MD. High consumption of fruits and nuts have been associated with lower risk for depression (20). Parletta et al. concluded that MD reduced depression $(p<0.05)$ and found a positive relationship between increased omega-3 intake and positive mental health (21). However, we found no significant correlation between students' compliance with the MD and their depression scores ( $p$ $>0.05$ ) which may be a result of our limited sample size and descriptive data without any intervention or follow up as well as data collection with participants' statements. In our study, compliance with the Mediterranean diet was found to be $75.8 \%$. Most of the students of the nutrition and dietetics (81\%), nursing (71.4\%) and physiotherapy $(73.8 \%)$ departments were found to be compatible with the Mediterranean diet. Since the participants studied at the faculty of health sciences, their departments did not affect their compliance with the MD (Table 1). In a study, the mean score of compliance with the Mediterranean diet was found to be $6.89 \pm 1.69$ in Turkey (22). In another study, the median diet score mean was found to be $6.15 \pm 2.16$ (23). In our study, the Mediterranean diet score mean was $7.65 \pm 1.8$. This difference may be due to the different sample groups. Furthermore, our results do not fairly represent university students in Turkey as the study is conducted in a private university in İstanbul and socioeconomic status and differences in food culture may affect food preferences and eating habits. Additionally, in a systematic review of the instruments for quantifying MD adherence, Zaragoza et al. (24) concluded that most scores were influenced by psychometric characteristics, thus only studies using the same scale are eligible to compare.

In a study conducted with university students, students' BDS mean score was found as $12.08 \pm 9.74$, with the lowest score zero and the highest score 50 (25). Temel et al. (26) found the mean BDS score of School of Health students as $13.43 \pm 8.45$. Ozdel et al.'s (27) mean score was $12.80 \pm 7.19$, Kaya et al. (28) found a score of $13.47+8.45$. In studies conducted using the same scale among university students in Turkey, this mean was determined by Aylaz et al. (29) as 10.84 , and Bostanci et al they reported it as 12.8 (30). In our study, BDS mean score was $9.23 \pm 6.6$. In our study, this rate was lower, which may be due to the exclusion of participants regarding cofounder factors including smoking and alcohol consumption. In a study of college students aged 17-25 in the United States, the average BDS score was $7.6 \pm 6.98$ (31). In our study and other studies conducted in Turkey, the scores were higher, which may be explained by social and economic developmental status differences between countries.

We found a positive significant relationship between energetic feeling and MD adherence $(p<0.05)$. However, emotional states of tense, angry and fatigued were higher in MD compatible group unexpectedly $(p<0.05)$. In a study conducted in Australia, disturbance, tension, depression, anger and confusion were found to be significantly low in individuals following MD ( $p<0.05)(32)$. In another study, it was observed that depression, anxiety, anger, fatigue, and confusion moods decreased when the diet was modified to the MD (33). A recent study found high stress levels in individuals with low consumption of fruits and vegetables. This relationship was higher in men than in women. In addition, they found no relationship between the sweets, cakes, and snacks score and stress and no relationship between the MD compliance score and stress (34). Another study conducted in 2018 found a significant association between adaptation to the Mediterranean diet and 
depression in men, while no significant association was found in women (35) which may suggest that the differences may arise from sex and we could not represent men fairly in our study.

The number of studies investigating the relationship between compliance with the MD and depression is limited in our country. As there are numerous factors which may contribute to depression and mood further studies are recommened to consider them as well as diet quality to point out appropriate interventions.

\section{Funding Source}

This research did not receive any funding.

\section{Conflict of Interest}

The authors declare no competing interest. 


\section{$\underline{\text { References }}$}

1. Gönder M. Determination of relationship between mediterranean diet score with anthropometric calculations and biochemical parameters on overweight and obese women. [Yüksek Lisans Tezi], Ankara, Gazi University; 2015.

2. Milaneschi Y, Bandinelli S, Penninx BW, Vogelzangs N, Corsi AM, Lauretani $F$ et al. Depressive symptoms and inflammation increase in a prospective study of older adults: a protective effect of a healthy (mediterranean-style) diet. Molecular Psychiatry. 2011;(16):589-90.

3. Henriquez-Sanchez P, Ruano C, de Irala $J$, Ruiz-Canela M, Martínez-González MA, Sánchez-Villegas A. Adherence to the Mediterranean diet and quality of life in the SUN Project. Eur J Clin Nutr. 2012;(66):360-8.

4. Lacatusu CM, Grigorescu ED, Floria M Onofriescu A, Mihai BM. The mediterranean diet: from an environmentdriven food culture to an emerging medical prescription. Int J Environ Res Public Health. 2019;(16):942.

5. World Health Organization (WHO), Depression [Internet], 2018. [cited 2019 Oct 20] Available from: https://www. who. int/news-room/fact-sheets/detail/ depression

6. World Health Organization (WHO), Depression in Europe [Internet], 2012. [cited 2019 Oct 20] Available from: https://www.euro.who.int/en/health-topic s/noncommunicable-diseases/mental-he alth/news/news/2012/10/depression-in-e urope/depression-in-europe-facts-and-fi gures

7. Özdel L, Bostancl M, Özdel O, Oğuzhanoğlu NK. Üniversite öğrencilerinde depresif belirtiler ve sosyodemografik özelliklerle ilişkisi. Anadolu Psikiyatri Derg. 2002;3(3): 155-61.

8. Ulas B, Tatlibadem B, Nazik F, Sonmez $M$, Uncu F. Üniversite öğrencilerinde depresyon sıklığı ve ilişkili etmenler. Celal Bayar Üniversitesi Sağlık Bilimleri Enstitüsü Derg. 2016;2(3):71-5.
9. Özenoğlu, A. Duygu durumu, besin ve beslenme ilişkisi. ACU Sağlık Bil Derg. 2018;9(4):357-65.

10. Tayfur M. Beslenme ve diyetetik güncel konular. Ankara: Hatipoğlu Yayınevi. 2018;(6):33-54.

11. Martinez-Gonzalez MA, Garcia-Arellano A, Toledo E, Salas-Salvado J, BuilCosiales P. A 14-item Mediterranean diet assessment tool and obesity indexes among high-risk subjects: $t$-The PREDIMED trial. 2012;7(8):e43134. DOI: 10.1371/journal.pone.0043134.

12. Pehlivanoğlu E, Balcıoğlu H, Ünlüoğlu I. Akdeniz diyeti bağlılık ölçeği'nin Türkçe'ye uyarlanması geçerlilik ve güvenilirliği. Osmangazi Tıp Derg. 2019;42(2):160-4.

13. Beck A, Ward C, Mendelson M, Mock J, Erbaugh J. An inventory for measuring depression. Arch Gen Psychiatry. 1961;(4):561-71. DOI:10.1001/archpsyc. 1961.01710120031004.

14. Tegin B. Depresyonda bilişsel bozukluklar: Beck modeline göre bir inceleme. [Doktora tezi], Hacettepe Üniversitesi; 1980.

15. Hisli N. Beck Depresyon envanterinin üniversite öğrencileri için geçerliği, güvenirliği. Psikoloji Derg. 1989;(7):3-13.

16. Mc Nair D, Lorr M, Droppleman L. Profile of mood states manual, educational and industrial testing. 1st ed. San Diego: Educational and Industrial Testing Service, 1981.

17. Selvi Y, Güleç $M$, Aydın A, Besiroğlu L. Psychometric evaluation of the Turkish language version of the profile of mood states (POMS). Journal of Mood Disorders. 2011;1(4):152-61.

18. World Health Organization (WHO). BMI classification [Internet], Global database on Body Mass Index. 2004 [cited 2019 Oct 20] Available from: http://www.assessmentpsychology.com/i cbmi.htm

19. M Corezzi, F Bert, G Lo Moro, A Buda, M $R$ Gualano, $R$ Siliquini. Mediterranean diet and mental health in university 
students: an Italian cross-sectional study. European Journal of Public Health. 2020;30(5):166-201.

20. Sanchez-Villegas A, Delgado-Rodríguez $M$, Alonso A, Schlatter J, Lahortiga F, Majem LS, et al. Association of the Mediterranean dietary pattern with the incidence of depression: the Seguimiento Universidad de Navarra/ University of Navarra follow-up (SUN) cohort. Archives of general psychiatry. 2009;66(10):1090-8.

21. Parletta N, Zarnowiecki D, Cho J, Wilson $A$, Bogomolova $S$, Villani $A$, et al. $A$ Mediterranean-style dietary intervention supplemented with fish oil improves diet quality and mental health in people with depression: A randomized controlled trial (HELFIMED). Nutr Neurosci. 2019;22(7):474-87.

22. Kalkuz Ş. Edirne il merkezinde yaşayan yetişkinlerin Akdeniz diyet skoru ile yaşam kalitesi arasındaki ilişkinin değerlendirilmesi. [Yüksek Lisans Tezi], Trakya, Trakya Üniversitesi; 2019.

23. Aşit M. Yetişkin Bireylerde Akdeniz Diyet Skoru ile Beslenme Alışkanlıkları ve Antropometrik Ölçümler Arasındaki Illişkinin Değerlendirilmesi, [Yüksek lisans tezi], Trakya, Trakya Üniversitesi; 2018.

24. Zaragoza-Martí A, Cabañero-Martínez MJ, Hurtado-Sánchez JA, Laguna-Pérez $A$, Ferrer-Cascales $R$. Evaluation of Mediterranean diet adherence scores: $A$ systematic review. BMJ Open. 2018;8(2):e019033.

25. Hür SD, Andsoy II, Şahin AO, Kayhan M, Eren S, Zünbül $N$ ve ark. Karabük Üniversitesi Sağlık Yüksekokulu öğrencilerinde depresif belirtiler. Journal of Psychiatric Nursing. 2014;5(2):72-6.

26. Temel E, Bahar A, Çuhadar D. Öğrenci hemşirelerin stresle baş etme tarzları ve depresyon düzeylerinin belirlenmesi. Fırat Sağlık Hizmetleri Derg. 2007;(2):107-18.

27. Özdel L, Bostancı M, Özdel O, Oğuzhanoğlu NK. Üniversite öğrencilerinde depresif belirtiler ve sosyodemografik özelliklerle ilişkisi,
Anadolu Psikiyatri Derg. 2002;(3): 155-61.

28. Kaya M, Genç M, Kaya B, Pehlivan E. Prevalence of depressive symptoms, ways of coping, and related factors among medical school and health services higher education students. Turk Psikiyatri Derg. 2007;(18):137-46.

29. Aylaz R, Kaya B, Dere N, Karaca Z, Bal Y. Sağlık Yüksekokulu Öğrencileri arasındaki depresyon sıklığı ve ilişkili etkenler. Anadolu Psikiyatri Derg. 2007;(8):46-51.

30. Bostanci M, Ozdel O, Oguzhanoglu NK, Ozdel L, Ergin A, Ergin $N$ et al. Depressive symptomatology among university students in Denizli, Turkey: prevalence and sociodemographic correlates. Croat Med J. 2005;(46):96-100.

31. Oliver JM, Paul JC. Self-esteem and self-efficacy: perceived parenting and family climate and depression in university students. J Clin Psychol. 1995;(51):467-81.

32. Wade AT, Davis CR, Dyer KA, Hodgson $J M$, Woodman RJ, Keage HAD, Murphy KJ. A Mediterranean diet supplemented with dairy foods improves mood and processing speed in an Australian sample: results from the MedDairy randomized controlled trial. Nutr Neurosci. 2020;23(8):646-58.

33. McMillan L, Owen L, Kras M, Scholey A. Behavioural effects of a 10-day Mediterranean diet. Results from a pilot study evaluating mood and cognitive performance.

Appetite. 2011;56(1):143-7.

34. El Ansari W, Berg-Beckhoff G. Nutritional correlates of perceived stress among university students in Egypt. Int $\mathrm{J}$ Environ Res Public Health. 2015;12(11):14164-76.

35. Adjibade M, Assmann KE, Andreeva VA, Lemogne C, Hercberg S, Galan P et al. Mediterranean diet and risk of depressive symptoms in the French SU.VI.MAX cohort. European Journal of Nutrition. 2018;(57):1225-35. 